\title{
The Effect of Terung Belanda (Cyphomandra betacea Sendtn.) Peels Fruit Extract on Tongue Cancer Cells
}

\author{
Janti Sudiono* and Hernandita Fasikhin \\ Oral Pathology Department, Faculty of Dentistry, Trisakti University, Indonesia
}

*Corresponding author: Janti Sudiono, Oral Pathology Department, Faculty of Dentistry, Trisakti University, Jl. Kyai

Tapa No.1, West Jakarta 11440, Indonesia

ARTICLE INFO

Received: 㓞 June 20, 2020

Published: 慧 June 30, 2020

Citation: Janti Sudiono, Hernandita Fasikhin. The Effect of Terung Belanda (Cyphomandra betacea Sendtn.) Peels Fruit Extract on Tongue Cancer Cells. Biomed J Sci \& Tech Res 28(4)-2020. BJSTR. MS.ID.004675.

Keywords: $70 \%$ Ethanol Extract of Tamarillo Peels; Decreased Viability; HSC3 cell
ABSTRACT

Oral cancer is a common malignancy in developing countries that $90 \%$ is squamous cell carcinoma with its most frequent predilection on the tongue. Treatments for tongue cancer include surgery, radiotherapy, and chemotherapy. However, those treatments generate various side effects. Herbal based treatment from the peels of tamarillo (Cyphomandra betacea Sendtn.) fruit is a new alternative one that is expected to minimize the side effects of modern therapies. The peels of tamarillo fruit contain polyphenolic compounds such as phenolic acid and flavonoid which allegedly have anticancer effect. Therefore, this study was conducted to determine the effect of $70 \%$ ethanol extract of tamarillo peels fruit on tongue squamous cell carcinoma (HSC-3) cell line viability. This in vitro experimental study consisted of treatment, positive and negative control groups. The treatment groups which were given the extract consisted of seven concentrations namely $20 \%, 10 \%, 5 \%, 2.5 \%, 1.25 \%, 0.625 \%$, and $0.3125 \%$. The culture medium without treatment was used as the negative control while $\mathrm{H}_{2} \mathrm{O}_{2}$ $3 \%$ used as the positive control. The result indicator was the cell viability test using a spectrophotometer with $450 \mathrm{~nm}$ wavelength. Data analysis used in this study was Shapiro-Wilk normality test, one-way Analysis of Variance Test (ANOVA), and post hoc LSD test. The $5 \%$ concentration of $70 \%$ ethanol extract tamarillo peels was no significant difference $(p>0,05)$ compared to those of positive control of $\mathrm{H}_{2} \mathrm{O}_{2} 3 \%$. Extract with $5 \%$ concentration is effective in decreasing the viability of HSC-3 cells.

\section{Introduction}

Oral cancer is one of the prime deadly cause in the world [1]. According to GLOBOCAN 2018, International Agency for Research on Cancer (IARC) revealed that there are 18.1 million new cases and 9.6 million deadly cases of cancer in the world. Oral cancer places the seventh level cases with the incidence as $\mathbf{5 7 2 . 0 0 0 ~ n e w ~ c a s e s ~}$ with 509.000 deadly cases [2]. Oral cancer is also one of malignancy cases that commonly occurred in developing countries [3] In Indonesia, head and neck cancer cases is around 3-4\% of all cancers with the dead rate as well as $2-3 \%$ [4]. Oral cancer is a subtype of head and neck cancers occurred within oral cavity. There are several types of oral cancers with $90 \%$ as squamous cell carcinoma [5]. Squamous cell carcinoma is malignant neoplasm arised from stratified squamous cells commonly occurred at lip, tongue, and mouth floor [6]. Apart of the increasing of therapies method, the morbidity and mortality rate of squamous cell carcinomas has not been significantly decreased during this last 30 years [7].
Therapy of squamous cell carcinoma consisted of surgical, radio and chemotherapy. However, this type of treatment has several side effects like pain and dryness of oral cavity, difficulties within speech, eat, swallowing and loss of taste function, problem of human metabolic process [8]. Therefore many research have been done to support alternative treatment that one of this by using natural herbal product. The natural product has lower side effect than those of conventional therapy included surgical, radio, and chemotherapy due to the lower toxicity toward normal cells [9]. Since several years ago, natural herbal product had been used as the prior of modern medicines to treat many diseases [8]. Developing countries included Indonesia consume a lot of natural herbal medicine caused of their afforded price [9]. In Indonesia, there is around 30.000 herbal plants that has potency as remedies and as much as 7.500 has already accepted and declared as herbal medicine [10]. Many researchs has been developed to search the potency of natural herbal product to treat diseases like cancer [11]. 
Around 54\% of anticancer medicine that has been accepted within the period of 1940-2002 derived from natural product [12]. Several herbal metabolit has strong anti-oxidant potential against free radical and decrease redoks imbalance. Several herbal medicines also have bioactive component to prevent the occurrence of initiation phase carcinogenesis process [13]. One of the herbal plants that has anti-cancer potential is terung Belanda (Cyphomandra betacea Sendtn.) [14]. Terung Belanda, oftenly named as tamarillo is declared has rich of natural antioxidant capacity due to its content of vitamin A, B6, C, E, and poliphenol compound [15]. The previous study already mentions that the peel of terung Belanda fruit has higher active antioxidant compound compared to the other parts [16]. Terung Belanda has anti-cancer potency as antioxidant and anti-proliferative activity of hepar cancer (HepG2) and mammae gland (MDA-MB-231) cells with no inhibition proliferation of rat's fibroblast normal cells (3T3) [17]. However, up to now, there is no research about the peel of terung Belanda fruit on tongue squamous cell carcinoma cells (HSC-3). The purpose of this study is to find out the effect of the peels of terung Belanda fruit on the viability of HSC-3 cells.

\section{Materials and Methods}

This study was done on September 2019 - November 2019 at Biology Research Centre of Indonesian Knowledge Department (LIPI) for plant determination test and at Integrated Laboratorium, Yarsi University for extraction process, phytochemical content, and viability test. This study is an experimental laboratoric in vitro. The material used is $70 \%$ ethanol extract of terung Belanda (Cyphomandra betacea Sendtn.) fruit peels with orange reddish colour. The sample of study is HSC-3 cells of Biobank Integrated Laboratory Yarsi University. The sample groups consisted of treatment, positive $\left(3 \% \mathrm{H}_{2} \mathrm{O}_{2}\right)$ and negative group. The treatment group consisted of several concentration groups as followed $20 \%$, $10 \%, 5 \%, 2.5 \%, 1.25^{\wedge}$, and $0.3125 \%$. The extract of terung Belanda fruit peels that has already been dried under the sun light was done by maceration technique used $70 \%$ ethanol for 72 hours. Then filtrated and evaporated to find out the crude extract. The extract was diluted to prepare several concentrations of $20 \%, 10 \%, 5 \%$, $2.5 \%, 1.25 \%$, and $0.6125 \%$. The phytochemical study was done on the extract.

\section{The culture medium used Dulbecco's Modified Eagle Medium (DMEM)}

10\% Fetal Bovine Serum (FBS) and 1\% of antibiotic (PenicillineStreptomycine) and antimycotic (Amphotericine B). Expansion culture and incubation was done for 24 hours. Cells were collected after 1 week of cultured and then cultured for 24 hours on 6 well plates with each of 15.000 cells. Put the Cell Counting Kit-8 (CCK-
8) reagent into well. After 1 hour, cells viability test could be done through microplate reader with wavelength of $450 \mathrm{~nm}$.

\section{Result}

Based on the determination test by Pusat Penelitian Biologi Lembaga Ilmu Pengetahuan (LIPI), the fruit used in this study is from the species of Solanum betaceum Cav. or namely Cyphomandra betacea Sendtn. The phytochemical test of the extract showed the contents of phenolic, flavonoid, tannin and alkaloid which was shown on Table 1. The result of viability test of the extract on HSC-3 cells was shown on Table 2 and Diagram 1. Exposure of the extract's concentrations $20 \%, 10 \%, 5 \%$ on HSC-3 cells showed the reduction of absorbance value while the increase of absorbances showed on the exposure of extracts concentrations 2,5\%, 1,25\%, 0,625\% dan 0,3125\%. The analysis of Terung Belanda (Cyphomandra Betacea Sendtn.) seed extract effect on viability HSC-3 cells on Table 3 showed the normal distribution with $\mathrm{p}>0.05$. The one-way Anova test showed the significant differences among concentration groups of Terung Belanda (Cyphomandra Betacea Sendtn.) seed extract with $\mathrm{p}<0.05$. The post hoc LSD test showed there were significant differences among concentrations of extract with the exception from concentrations of $20 \%, 10 \%, 5 \%$. There were also significant differences among control group and concentrations of extract except for $5 \%$ concentration with positive control and concentrations of $1,25 \% ; 0,3125 \% ; 0,625 \%$ with negative control group (Table 4).

Table 1: The result of phytochemical test of Cyphomandra Betacea Sendt.

\begin{tabular}{|c|c|c|c|}
\hline No. & $\begin{array}{l}\text { Secondary } \\
\text { metabolite }\end{array}$ & Method of test & Result \\
\hline 1. & Phenolic & Reagent $\mathrm{FeCl}_{3} 5 \%$ & + \\
\hline \multirow{3}{*}{2.} & \multirow{3}{*}{ Flavonoid } & $\begin{array}{l}\text { a. reagent } \mathrm{HCl} \text { pekat } \\
+\mathrm{Mg}\end{array}$ & + \\
\hline & & b. reagent $\mathrm{H}_{2} \mathrm{SO}_{4} 2 \mathrm{~N}$ & + \\
\hline & & c. reagent $\mathrm{NaOH} 10 \%$ & + \\
\hline 3. & Steroid & $\begin{array}{l}\text { Reagent Lieberman- } \\
\text { Burchard }\end{array}$ & - \\
\hline 4. & Triterpenoid & $\begin{array}{l}\text { Reagent Lieberman- } \\
\text { Burchard }\end{array}$ & - \\
\hline 5. & Saponin & Reagent $\mathrm{HCl}+\mathrm{H}_{2} \mathrm{O}$ & - \\
\hline 6. & Tannin & Reagent $\mathrm{FeCl}_{3} 1 \%$ & + \\
\hline \multirow{4}{*}{7.} & \multirow{4}{*}{ Alkaloid } & a. reagent Hager & + \\
\hline & & b. reagent Wagner & + \\
\hline & & c. reagent Dragendorff & + \\
\hline & & d. reagent Mayer & + \\
\hline
\end{tabular}




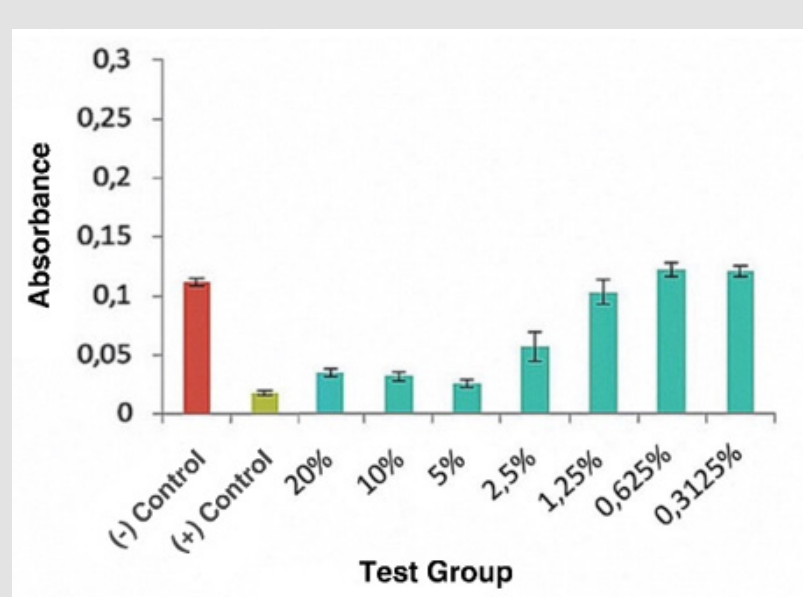

Figure 1: The absorbance value of viability tests several concentrations of Terung Belanda (Cyphomandra Betacea Sendtn.) seed extract, negative and positive control on HSC-3 cells.

Table 2: Viability test of terung Belanda (Cyphomandra Betacea Sendtn.) seed extract on HSC-3 cells after 24 hours incubation.

\begin{tabular}{|c|c|c|}
\hline Material tested & $\mathbf{N}$ & $\mathbf{X} \pm \mathbf{S D}^{*}$ \\
\hline Negative control (-) & 3 & $0.112 \pm 0.003$ \\
\hline $\begin{array}{c}\text { Positive control (+) } \\
\text { with } \mathrm{H}_{2} \mathrm{O}_{2} 3 \%\end{array}$ & 3 & $0.018 \pm 0.002$ \\
\hline Extract (20\%) & 3 & $0.035 \pm 0.004$ \\
\hline Extract (10\%) & 3 & $0.032 \pm 0.004$ \\
\hline Extract (5\%) & 3 & $0.025 \pm 0.003$ \\
\hline Extract (2.5\%) & 3 & $0.057 \pm 0.012$ \\
\hline Extract (1.25\%) & 3 & $0.103 \pm 0.012$ \\
\hline Extract (0.625\%) & 3 & $0.122 \pm 0.006$ \\
\hline Extract $(0.3125 \%)$ & 3 & $0.121 \pm 0.005$ \\
\hline
\end{tabular}

Note: *mean of $3 \times$ measurement $(\mathrm{mg} / \mathrm{mL})$

Table 3: Normality test of HSC-3 cells viability data.

\begin{tabular}{|c|c|c|c|c|}
\hline \multirow{2}{*}{\multicolumn{2}{|c|}{ Tested groups }} & \multicolumn{3}{|c|}{ Shapiro-Wilk } \\
\hline & & \multirow{2}{*}{$\begin{array}{c}\text { Statistic } \\
0,842\end{array}$} & \multirow{2}{*}{$\frac{\text { Df }}{3}$} & \multirow{2}{*}{$\begin{array}{l}\text { Sig. } \\
0,220\end{array}$} \\
\hline \multirow{7}{*}{$\begin{array}{l}\text { Cyphomandra betacea } \\
\text { Sendtn pill fruit extract }\end{array}$} & $20 \%$ & & & \\
\hline & $10 \%$ & 0,987 & 3 & 0,780 \\
\hline & $5 \%$ & 0,855 & 3 & 0,253 \\
\hline & $2,5 \%$ & 0,778 & 3 & 0,062 \\
\hline & $1,25 \%$ & 0,842 & 3 & 0,220 \\
\hline & $0,625 \%$ & 0,999 & 3 & 0,927 \\
\hline & $0,3125 \%$ & 0,881 & 3 & 0,328 \\
\hline \multirow{2}{*}{ Control } & Negative & 0,993 & 3 & 0,843 \\
\hline & Positive & 0,987 & 3 & 0,780 \\
\hline
\end{tabular}

Table 4: One-way Anova test of HSC-3 cells viability data.

\begin{tabular}{|c|c|c|c|c|c|}
\hline Viability & $\begin{array}{c}\text { Sum of } \\
\text { quadrat }\end{array}$ & df & Mean & F & Sig. \\
\hline $\begin{array}{c}\text { Among } \\
\text { groups }\end{array}$ & 0,056 & 9 & 0,006 & 106,722 & 0,000 \\
\hline $\begin{array}{c}\text { Within } \\
\text { group }\end{array}$ & 0,001 & 20 & 0,000 & & \\
\hline Total & 0,057 & 29 & & & \\
\hline
\end{tabular}

\section{Discussion}

The phytochemical contents of terung Belanda peel fruit are polyphenolic compound such as phenolic acid and flavonoid. Polyphenolic compound suspected to have anticancer effect that inhibit cell cycle on the G1/S and G2/M phase and induce apoptotic process [18]. In this study, anticancer activity of terung Belanda peel fruit was tested on HSC-3 cells viability. This viability test was done to find out the viable cells after exposure of tested agent [19]. This study is CCK-8 colorimetry method used tetrazolium salt WST8 reagent that produce orange color of formazan while contacted to viable cell [20]. In this study, there was reduction of absorbances value on several concentrations extract $(20 \%, 10 \%$, and $5 \%)$ groups. The higher reduction value is following the lower concentration of extracts. The higher polyphenolic compound content of extract tends to increase mutagen potency within cells due to its quite high concentratrion of quercetin content within flavonoid that increase reactive oxygen species production to promote DNA mutation [21].

Reactive oxygen species will attact macromolecule such as protein, fat, and nucleic acid therefore macromolecule alteration resulted in DNA mutation and progressive proliferative activity of mutagenic cells [15]. On the other hand, viability test within several extraction groups $(2.5 \%, 1.25 \%, 0.625 \%$ and $0.3125 \%)$ showed increase of absorbance values. This suggested that decrease of polyphenolic compound content within extract have lower citotoxicity effect. The 5\% concentration of extract showed the highest potency against HSC-3 cells viability compared to other concentrations. There is also showed that by post hoc LSD there was no significant difference between $5 \%$ concentration of extract with those of positive control $\mathrm{H}_{2} \mathrm{O}_{2} 3 \%$ group. This result suggested that $5 \%$ concentration of extract is the effective concentration to reduce HSC-3 cells viability. This result supported the previous study that ethanol extract of terung Belanda as anticancer property through its antioxidant activity and anti-proliferative on Hepar Cancer Cell (HepG2) and adeno cancer of mammae (MDA-MB-231) that show no toxic effect on normal fibroblast cells [22]. The previous study revealed that polyphenolic compound content of terung Belanda, in form of phenolic acid and flavonoid suspected has anticancer potency [16].

The phytochemical test in this study showed that the ethanol extract of terung Belanda fruit peel contain polyphenolic compound as phenolic acid and flavonoid as shown on Table 1. The phenolic 
acid and flavonoid have anticancer potency by disturbances of initiation, proliferation and cancer developing process through tumor suppressor gene (p53) increase. The increase of p53 induces cycle cell inhibition on G1/S and G2/M phase as checkpoint cell cycle. This checkpoint has role to detect mutant DNA gene of cell. The inhibition of cell cycle gives the time for regeneration of DNA destruction $[23,24]$. In case of the highest destruction of DNA, the polyphenolic compound induces apoptosis through inhibition of antiapoptotic protein expression (BCL-2 dan BCL-X) and activation of proapoptotic protein (BAX dan BAK) by p53 protein. The activation of proapoptotic protein causes release of cytochrome c into cytoplasm by the changes of membrane permeability of mitochondria. Cytochrome c links to Apoptotic Protease Activating Factor 1 (APAF1) and pro-caspase- 9 to activate caspase 9. Caspase 9 links to pro-caspase- 3 to activate caspase 3. Caspase 3 activates DNAse to DNA fragmented on cell therefore induce the apoptotic process [25].

\section{Conclusion}

Among concentrations of terung Belanda (Cyphomandra betacea Sendtn.) ethanol $70 \%$ extract, $5 \%$ concentration is an effective concentration to reduce viability of HSC-3 (Human Oral Squamous Carcinoma) cell. There is also no significant difference of this concentration with those of $\mathrm{H} 2 \mathrm{O} 23 \%$ as control positive.

\section{References}

1. (2015) Info Datin Pusat Data dan Informasi Kementrian Kesehatan RI. Situasi penyakit kanker. Jakarta: Kementrian Kesehatan RI.

2. (2018) International Agency for Research on Cancer. Latest global cancer data: Cancer burden rises to 18.1 million new cases and 9.6 million cancer deaths in 2018. World Health Organization.

3. Montero PH, Patel SG (2015) Cancer of the oral cavity. Surg Oncol Clin N Am 24(3): 491-508.

4. Sirait AM (2013) Faktor risiko tumor/kanker rongga mulut dan tenggorokan di Indonesia (Analisis Riskesdas 2007). Media Litbangkes 23(3): 122-129.

5. Polz gruszka D, Macieląg P, Fołtyn S, Polz-dacewicz M (2014) Ora squamous cell carcinoma (OSCC) - molecular, viral and bacterial concepts. J Pre-Clinical Clin Res 8(2): 61-66.

6. Rivera C, Venegas B (2014) Histological and molecular aspects of oral squamous cell carcinoma (Review). Oncol Let 8(1): 7-11.

7. Markopoulos AK (2012) Current aspects on oral squamous cell carcinoma. Open Dent J 6: 126-130.

8. (2019) American Cancer Society. Treating oral cavity and oropharyngeal cancer. New York: American Cancer Society.
9. Seca AML, Pinto DCGA (2018) Plant secondary metabolites as anticancer agents: successes in clinical trials and therapeutic application. Int J Mol Sci 19(1): 263-284

10. Qazi MA, Molvi KI (2016) Herbal medicine: a comprehensive review. Int J Pharm Res 8: 1-5.

11. Aziz ZAA, Ali SAM, Ahmad A, Mohd Setapar SH (2016) Application of herbal extract and its medicinal value. Der Pharm Lett 8(9): 161-167.

12. Salim Z, Munadi E (2017) Info komoditi tanaman obat. Jakarta: Badan Pengkajian dan Pengembangan Perdagangan Kementerian Perdagangan Republik Indonesia.

13. Greenwell M, Rahman PKSM (2015) Medicinal plants: their use in anticancer treatment. Int J Pharm Sci Res 6(10): 4103-4112.

14. Yuan H, Ma Q, Ye L, Piao G (2016) The traditional medicine and modern medicine from natural products. Molecules 21(5): 559-576.

15. Maisarah AM, Asmah R, Faisal A, Rajesh R (2017) Nutritional compositions and antiproliferative activities of different solvent fractions from ethanol extract of cyphomandra betacea (tamarillo) fruit. Malays J Med Sci 24(5): 19-32.

16. Hassan SHA, Bakar MFA (2013) Antioxidative and anticholinesterase activity of cyphomandra betacea fruit. Sci World J p. 1-7.

17. Widayanti NP, Puspawati NM, Suarsana IN, Asih IARA (2016) Aktivitas antioksidan fraksi n-butanol ekstrak kulit terong belanda (solanum betaceum cav.) secara in vitro dan identifikasi senyawa golongan flavonoidnya. Cakra Kim (Indonesian E-Journal Appl Chem) 4(1): 30-38.

18. Katyal P, Bhardwaj N, Khajuria R (2014) Flavonoids and their therapeutic potential as anti cancer agents: mechanism, factors, and regulation. World J Pharm Pharm Sci 3(6): 2188-2216.

19. Riss TL, Moravec RA, Niles AL, Duellman S, Benink HA, et al. (2019) Cell viability assays. Assay guidance manual pp. 295-320.

20.(2018) Dojindo Molecular Technologies. Measuring cell viability/ cytotoxicity. Washington DC: Dojindo Molecular Technologies.

21. Forbes AM, Lin H, Meadows GG, Meier GP (2014) Synthesis and anticancer activity of new flavonoid analogs and inconsistencies in assays related to proliferation and viability measurements. Int J Oncol 45(2): 831-842.

22. Mutalib MA, Ali F, Othman F, Ramasamy R, Rahmat A (2016) Phenolics profile and anti-proliferative activity of cyphomandra betacea fruit in breast and liver cancer cells. Springerplus 5(1): 2105.

23. Karak P (2019) Biological activities of flavonoids: an overview. Int J Pharm Sci Res 10(4): 1567-1574.

24. Katyal P, Bhardwaj N, Khajuria R (2014) Flavonoids and their therapeutic potential as anti cancer agents: mechanism, factors and regulation. World J Pharm Pharm Sci 3(6): 2188-2216.

25. Veeramuthu D, Raja WRT, Al Dhabi NA, Savarimuthu I (2017) Flavonoids: anticancer properties. In: Justino J (Ed.) Flavonoids from biosynthesis to human health. Croatia: InTech pp. 287-304. 
ISSN: 2574-1241

DOI: 10.26717/BJSTR.2020.28.004675

Janti Sudiono. Biomed J Sci \& Tech Res

(c) (P) This work is licensed under Creative

Submission Link: https://biomedres.us/submit-manuscript.php

$\begin{array}{ll}\text { BIOMEDICAL } & \text { Assets of Publishing with us } \\ \text { RESEARCHES } & \text { - Global archiving of articles } \\ \text { - Immediate, unrestricted online access }\end{array}$

